DOI: 10.34015/2523-4552.2019.4.08

УдК 342.9

Брусакова О. В., кандидат філософських наук, декан факультету № 6 Харківського національного університету внутрішніх справ ORCID: 0000-0001-8616-042

\title{
АДМІНІСТРАТИВНО-ПРАВОВЕ ЗАБЕЗПЕЧЕННЯ ПУБЛІЧНОГО ПОРЯДКУ І БЕЗПЕКИ НА АВІАЦІЙНОМУ ТРАНСПОРТІ
}

Статтю спрямовано на розкриття особливостей адміністративноправового забезпечення публічного порядку і безпеки на авіаційному транспорті. В роботі охарактеризовано властивості авіаційного транспорту, його сучасний стан та вектор розвитку. Досліджено склад та структуру нормативно-правової бази, якою регулюється зазначена сфера діяльності. Розглянуто комплекс питань, що стосується безпеки в авіації, приділено увагу системі суб'єктів, діяльність яких спрямована на ії забезпечення. Уточнено співвідношення понять «публічний порядок на авіаційному транспорті» та «авіаційна безпека», зроблено висновки про застосування різних видів правових режимів, що мають місце в авіації, а також про складну систему комунікацій між суб'єктами, які забезпечують додержання цих режимів.

Ключові слова: авіаційна безпека; публічний порядок; громадська безпека; національна безпека.

Статья направлена на раскрытие особенностей административноправового обеспечения общественного порядка и безопасности на авиационном транспорте. В работе охарактеризованы свойства авиационного транспорта, его современное состояние и вектор развития. Проведено исследование состава и структуры нормативно-правовой базы, которой регулируется указанная сфера деятельности. Рассмотрен комплекс вопросов, касающихся безопасности в авиации, уделено внимание системе субъектов, деятельность которых направлена на ее обеспечение. В результате проведения анализа норм законодательства и наработок ученых, уточнено соотношение понятий «публичный порядок на авиационном транспорте» и «авиационная безопасность», сделаны выводы о применении различных видов правовых режимов, имеющих место в авиации, а также о сложной системе коммуникаций между субъектами, которые обеспечивают соблюдение этих режимов.

Ключевые слова: авиационная безопасность; общественный порядок; общественная безопасность; национальная безопасность.

Постановка проблеми. Авіаційна галузь $є$ складовою частиною транспортної системи України, яка пов'язана із використанням повітря- 
ного простору. Визначення авіації як самостійної галузі, свого часу, містив Повітряний кодекс України 1993 року. У ньому декларувалось, що авіаційна галузь охоплює усі види підприємств, організацій та установ, діяльність яких спрямована на створення умов та використання повітряного простору людиною за допомогою повітряних суден [1].

Інтенсивний розвиток авіаційної галузі визнається Україною одним $з$ важливих напрямків економічного розвитку нашої держави та передбачений Національною транспортною стратегією України на період до 2030 року [2]. Важка економічна й військово-політична ситуація в країні ускладнює виконання цього завдання. Водночас з цим, законодавча база України, яка регулює систему гарантування безпеки авіаційних перевезень продовжує активно реформуватись.

Необхідно відмітити, що різновидами авіації наразі є: авіація загального призначення, цивільна, комерційна, державна, військова, тощо. Кожна з них здійснює транспортування людей та вантажів. Складність побудови авіаційної галузі та особливості їі інфраструктури призводять до того, що при порушенні вимог безпеки, резонансі наслідки можуть мати не лише тяжкі злочини але й дрібні порушення. Зазначені особливості підвищують важливість забезпечення публічного порядку і безпеки на авіаційному транспорті.

Аналіз останніх досліджень і публікацій. Розгляду питань, що стосуються охорони громадського порядку та безпеки присвячений велика кількість наукових праць. Багато вчених зосереджували свою увагу на роз- гляді публічного порядку саме на транспорті, зокрема аналізували окремі питання забезпечення безпеки в авіації та при здійсненні авіаційного транспортування, серед них: В. Авер'янов, Я. Баган, О. Бандурка, Д. Бахрах, В Бесчастний, В. Бевзенко, О. Безпалова, Ю. Битяк, А. Бичков, Н. Бортник, С. Братусь, І. Булгакова, В. Вайцман, В. Волік, М. Гаєвець, А. Гаркуша, С. Гончарук, Н. Губерська, Т. Гуржій, С. Гусаров, Н. Дараганова, Е. Деркач, О. Джафарова, О. Домашенко, О. Доценко, В. Іжевський, А. Калініченко, Р. Калюжний, I. Козачок, В. Колпаков, Т. Коломоєць, В. Кононець, А. Комзюк, О. Кузьменко, Д. Малишко, Р. Мельник, М. Mixровська, В. Міщук, О. Миколенко, О. Панова, А. Подоляка, Д. Приймаченко, О.Сапронов, Є.Скрипа, С. Стеценко, М. Стоцька, М. Тищенко, Є. Федорчук, А. Філіппов, С. Шатрава, Х. Шварц, М. Шелухін, А. Школик, О.Ярмиш. Проте, вважати тему авіаційної безпеки достатньо дослідженою і повністю розкритою неможна. Досліджень спрямованих на розкриття особливостей публічної безпеки саме в сфері авіації досить небагато, що потребує подальшої роботи у цьому напрямку.

3 початку 2019 року до сьогодення практична діяльність у напрямку розбудови нормативноправового забезпечення авіаційної галузі України, в тому числі на міжнародному рівні, була досить насиченою. Наприклад:

внесена низка змін до Кодексів і Законів України (у Повітряний кодекс України, Державну програму авіаційної безпеки цивільної авіації, тощо);

видано 9 нормативних Актів Кабінету Міністрів України; 
- затверджено 4 спільні Накази органів виконавчої клади;

- прийнято 13 авіаційних Правил України;

- розроблено та підписано низку міжнародних документів, серед яких напряму стосуються безпеки, наприклад: Меморандум про взаєморозуміння щодо розвитку безпеки цивільної авіації між Державною авіаційною службою України та Агентством цивільної авіації Грузії; Меморандум про взаєморозуміння між Державною авіаційною службою України та Генеральною дирекцією цивільної авіації Туреччини щодо розвитку безпеки цивільної авіації та встановлення процедури співробітництва між Сторонами у сфері льотної придатності;

- $\quad$ в той же час, державою запланована та ведеться робота по переоснащенню та реконструкції аеропортів України. Впродовж наступних 10-ти років планується збільшити кількість діючих аеропортів майже у 2-а рази, в результаті чого їх загальна кількість становитиме більше ніж 50-т штук;

- Голова Державної авіаційної служби України (Державіаслужби) О. Більчук звітує про збільшення, у порівнянні з 2018 роком: пасажиропотоку в аеропортах України на $18,4 \%$, пошто- і вантажопотоку на $6,7 \%$, кількості виконаних рейсів на $10,1 \%$, обслуговування польотів у повітряному просторі України на $11,5 \%$ [3].

Усі перелічені зміни та досягнення демонструють динамічність розвитку авіаційній галузі України. Все перелічене напряму або опосередковано відбивається на рівні безпеки і публічного порядку в здійсненні авіаційних перевезень, що і обумов- лює актуальність й важливість цього дослідження.

Постановка завдання. Метою даної наукової роботи є дослідження особливостей адміністративноправового забезпечення публічного порядку i безпеки на авіаційному транспорті. Досягнення цієї цілі потребує виконання таких завдань, як: надати характеристику авіаційному транспорту та дослідити склад i структуру нормативно-правової бази, якою регулюється зазначена сфера діяльності; визначити зміст безпеки на авіаційному транспорті та співвідношення iㅣ складових, окреслити адміністративно-правову основу забезпечення публічного порядку і безпеки авіаційних перевезень, розглянути поняття правових режимів та їх вплив на забезпечення безпеки, визначити систему суб'єктів громадської безпеки в цивільній авіації, дослідити особливості комунікацій між ними, зробити висновки щодо проведеного дослідження та особливостей адміністративно-правового забезпечення публічного порядку на авіаційному транспорті.

Виклад основного матеріалу. Повітряний кодекс України поділяє авіацію на дві великі групи: державну та цивільну. Підтримання і організація безпеки на кожній 3 них залежить від змісту та специфіки завдань, які покладаються на зазначені групи авіації.

Державна авіація використовує повітряні судна з метою забезпечення національної безпеки і оборони держави та захисту населення, які покладаються на Збройні Сили України (та) інші військові формування [4, ч. 4 ст. 4 розділу II], уповноваженим органом виконавчої влади в галузі державної авіації $є$ Міністерс- 
тво оборони України [4, ч. 6 ст. 4 розділу II].

Функція оборони традиційно пов'язана із Збройними Силами України. Вона завжди спрямована на забезпечення воєнної безпеки, захист від збройної агресії та воєнних загроз. Що ж до сутності і змісту «національної безпеки», то дискусії у науковому середовищі, що до неї i досі ведуться. Проте, Закон надає досить чітке визначення цьому поняттю. Термін «національна безпека України» визначено, як захищеність державного суверенітету, територіальної цілісності, демократичного конституційного ладу та інших національних інтересів України від реальних та потенційних загроз $[5$, п. 9 ч. 1 ст. 1 розділу I].

Наведені визначення демонструють специфіку видів безпеки і дають нам підстави стверджувати, що сфера державної авіації не потребує забезпечення публічного порядку та безпеки оскільки функціонує поза їх межами.

Для пояснення цього висновку процитуємо С. П. Пономарьова. У своïх наукових працях він доводив, що відповідно до головних видів безпеки, які дістали поширення в Українській державі, слід розрізняти три основні елементи сектора безпеки: 1. Особиста безпека громадян, громадський порядок тощо, які забезпечують правоохоронні органи; 2. Національна безпека - забезпечують спецслужби; 3. Військова безпека - забезпечує Воєнна організація України [6, с. 94]. Таким чином діяльність державної авіації стосується лише двох останніх видів безпеки.

Друга велика група авіації авіація цивільна. Законодавство міс- тить наступне визначення цивільній авіації - це частина авіації, що задовольняє потреби держави і громадян у повітряних перевезеннях і авіаційних роботах та виконанні польотів у приватних цілях і поділяється на комерційну авіацію та авіацію загального призначення [4, ч. 4 ст. 4 розділу II].

Безпека цивільної авіації має специфічну притаманну лише їй структуру та особливості. У великій кількості нормативно-правових актів використовується термін «авіаційна безпека». Значення цього поняття закріплено у Повітряному кодексі України. Наразі під «авіаційною безпекою» розуміють - захист цивільної авіації від актів незаконного втручання, який забезпечується комплексом заходів із залученням людських і матеріальних ресурсів [4, п. 2 ч. 1 ст. 1 розділу I].

Також у Повітряному кодексі України застосовується термін «безпека авіації». В свою чергу, вище згадана «авіаційна безпека», разом із безпекою польотів, екологічною безпекою, економічною та інформаційною безпекою, $€$ iï структурними складовими [4, ч. 1 ст. 10 розділу III]. Таким чином, «безпека авіації» включає в себе низку питань безпеки із сумісних, таких, що виходять за межі авіації, сфер. Наприклад, екологія, економіка та інформація. Ця особливість обумовлює широке коло суб'єктів (органів та структур), задіяних у підтриманні безпеки цивільної авіації. Разом з тим, необхідно відмітити, що термін безпека авіації також має визначення у чинному законодавстві і представляє собою: стан галузі цивільної авіації, за якого ризик завдання збитків людям чи 
майну знижується до прийнятного рівня... [4, п. 20 ч. 1 ст. 1 розділу I].

Спираючись на викладене можна стверджувати, що «публічний порядок і безпека» на авіаційному транспорті реалізуються саме в «цивільній авіації». Водночас з тим перетинаючись із специфічною для цієї галузі сферою «безпеки авіації».

Встановивши місце, яке займає забезпечення публічного порядку та безпеки на авіаційному транспорті, необхідно уточнити та розкрити зміст самого поняття «публічний порядок».

Наразі єдиний підхід до визначення поняття публічного порядку в науці відсутній. Публічний порядок ототожнюють 3 громадським порядком, декілька визначень якого містяться в законодавстві України [7]. Узагальнивши їх, можна тлумачити громадський порядок, як сукупність суспільних відносин, які складаються і розвиваються в громадських місцях під впливом правових та соціальних норм, що забезпечують нормальні умови життєдіяльності людини, діяльності підприємств, установ і організацій, спрямованих на забезпечення їх нормального функціонування, повагу до людської гідності, честі та громадської моралі.

Юридична енциклопедія дає схоже визначення публічному поряду та трактує його, як врегульовану правовими та іншими соціальними нормами систему суспільних відносин, що забезпечує захист прав і свобод громадян, їхнього життя, здоров'я, повагу до честі та людської гідності, дотримання норм суспільної моралі [8]. Таке визначення $\epsilon$ досить об'ємним, охоплює широке коло суспільних відносин та фактич- но збігається із змістом категорії «правопорядок».

Більшість науковців вважають, що публічний порядок необхідно розглядати принаймні у двох аспектах, а саме: у широкому та вузькому (поліцейському) розумінні. А. Подоляка, зазначає, що у широкому (соціально-політичному) аспекті публічний порядок варто розглядати у значенні суспільного ладу, як весь устрій суспільства, всю систему відносин, що існують у суспільстві [9]. Як відмічає В. Кононець, публічний порядок у вузькому (поліцейському) розумінні $\epsilon$ системою суспільних відносин, які виникають та розвиваються в громадських місцях у процесі спілкування між людьми, правове регулювання яких забезпечує як особисту безпеку людини, так і публічну безпеку, і охорону яких законодавством віднесено до компетенції органів внутрішніх справ [10, с. 13].

I. Веремеєнко стверджує, що сутність публічного порядку становлять три складові: місце виникнення суспільних відносин, їхній зміст та основна мета регулювання [11]. Відповідно у нашому дослідженні просторовими межами виникнення публічних суспільних відносин є: територія аеропортів, аеровокзалів і прилеглі до них території, а також зони повітряних суден. А змістом і основною метою регулювання виступають заходи спрямовані на дотримання правил поведінки у зазначених просторових межах.

Окремо необхідно звернути увагу на співвідношення понять «публічна безпека» та «публічний порядок». Нажаль єдиної думки щодо визначення цих термінів серед науковців на даний час теж не має. Частина вважає їх подібними один до одного, 
інші розмежовують ці поняття. Проте, ми вважаємо корисними щодо цього питання погляди Т. Мінка, згідно яких змістом охорони публічного порядку є забезпечення безпеки. Тобто публічний порядок встановлюється та існує для того, аби була забезпечена публічна безпека. Звідси, публічний порядок $є$ складовою громадської (публічної) безпеки [12].

Разом 3 тим, законодавством України так розкривається зміст поняття «громадська безпека і порядок»: це захищеність життєво важливих для суспільства та особи інтересів, прав і свобод людини і громадянина, забезпечення яких $є$ пріоритетним завданням діяльності сил безпеки, інших державних органів, органів місцевого самоврядування, ïx посадових осіб та громадськості, які здійснюють узгоджені заходи щодо реалізації і захисту національних інтересів від впливу загроз [5, п. 3 ч. 1 ст. 1 розділу I].

Ми вже встановили, що забезпечення публічного порядку віднесено законодавством переважно до компетенції органів внутрішніх справ. Конкретизуючи цей висновок, основним суб'єктом, що забезпечує публічний порядок та безпеку на авіаційному транспорті слід визнати Національну поліцію України.

У Національній поліції України компетенція втілювати державну політику у сфері забезпечення публічної безпеки і порядку, здійснювати превентивну та профілактичну роботу безпосередньо в аеропортах, аеровокзалах, прилеглих до них територіях належить «сектору превентивної діяльності поліції в аеропортах», який у свою чергу входить до Департаменту поліції превентивної діяльності.
Діяльність Департаменту поліції превентивної діяльності регламентується Конституцією та законами України, указами Президента України, постановами Верховної Ради України, актами Кабінету Міністрів України, іншими нормативноправовими актами та Положенням про Департамент превентивної діяльності Національної поліції України, затвердженим Наказом Національної поліції України від 27.11.2015 року № 123 [13].

Згідно зазначеного Положення про Департаменту превентивної діяльності Національної поліції України, Департаменту належить виконання наступних основних завдань [13]:

1) вжиття заходів з організації забезпечення публічної безпеки i порядку на вулицях, площах, у парках, скверах, на стадіонах, вокзалах, в аеропортах, морських та річкових портах, інших публічних місцях, зокрема під час проведення масових (мирних зібрань, культурновидовищних та публічних релігійних заходів, виборів та референдумів) та спортивних (футбольних матчів та інших масштабних спортивних змагань) заходів, організації формування відповідних обліків, запобігання та припинення групових порушень (громадського) порядку, масових заворушень;

2) організація та здійснення регулювання дорожнього руху, контроль за додержанням Правил дорожнього руху його учасниками та за правомірністю експлуатації транспортних засобів на вуличнодорожній мережі, а також забезпечення супроводження транспортних засобів у випадках, передбачених законом. Аналіз обставин і причин виникнення дорожньо-транспортних пригод 
на вулично-дорожній мережі. Контроль за дотриманням власниками транспортних засобів, а також громадянами, посадовими і службовими особами вимог Закону України «Про дорожній рух», правил, норм та стандартів з питань забезпечення безпеки дорожнього руху, які регламентують вимоги щодо технічного стану транспортних засобів та охорони довкілля від шкідливого їх впливу;

3) контроль за дотриманням фізичними і юридичними особами спеціальних правил і порядку зберігання та використання зброї, спеціальних засобів індивідуального захисту й активної оборони, боєприпасів, вибухових речовин і матеріалів, інших предметів, матеріалів та речовин, на які поширюється дозвільна система.

Основними функціями поліції превентивної діяльності в аеропортах згідно вище зазначеного Положення $є$ [13]:

- захист прав, свобод та законних інтересів громадян, запобігання правопорушенням та їх припинення;

- забезпечення охорони громадського порядку та громадської безпеки на вулицях та в інших громадських місцях (у тому числі у місцях проведення масових заходів), профілактика правопорушень у взаємодії з іншими службами і підрозділами Національної поліції, органами державної влади та місцевого самоврядування, а також об'єднаннями громадян;

- організація проведення загальної та профілактичної роботи серед населення, взаємодії з громадськими формуваннями щодо охорони громадського порядку, участі разом 3 іншими службами та підрозділами Національної поліції у вияв- ленні, попередженні та припиненні правопорушень;

- здійснення ліцензування певних видів господарської діяльності, забезпечення дозвільної системи та державного охоронного нагляду;

- забезпечення охорони затриманих і взятих під варту осіб під час їх тримання у спеціальних установах поліції та конвоювання до органів суду, прокуратури та досудового слідства;

- організація і контроль за станом виконання підпорядкованими підрозділами превентивної діяльності нормативно-правових актів;

- реалізація в межах своєї компетенції державної політики щодо забезпечення безпеки дорожнього руху;

- організація контролю за додержанням законів, інших нормативних актів з питань безпеки дорожнього руху та охорони навколишнього середовища від шкідливого впливу автомототранспортних засобів;

- удосконалення регулювання дорожнього руху з метою забезпечення його безпеки та підвищення ефективності використання транспортних засобів;

- виявлення та припинення фактів порушення безпеки дорожнього руху, а також виявлення причин і умов, що сприяють їх вчиненню.

За даними В. Кононця, під час охорони публічного порядку та безпеки у аеропортах за оцінкою працівників поліції найчастіше використовуються [10, с. 94]:

1. Безпосереднє забезпечення охорони аеровокзалу і прилеглої території;

2. Підтримання публічного порядку в контрольованій зоні аеропорту; 
3. Виявлення осіб, що викликають підозру у вчиненні правопорушень шень;

4. Профілактика правопору-

5. Оперативно-профілактичні заходи щодо виявлення порушень паспортного режиму;

6. Контроль за наявністю несправного або безхазяйного транспорту, який знаходиться поблизу споруд аеропорту;

7. Режимно-оглядові заходи 3 метою недопущення провозу зброї, боєприпасів i вибухових речовин;

8. Регулювання пасажиропотоків при проведенні масових нестандартних перевезень;

9. Постійна взаємодія з УМВС і СБУ щодо обміну оперативною інформацією стосовно питань безпеки в аеропортах;

10. Негайне реагування, з виїздом слідчооперативних груп УМВС на місце події для перевірки будьякої інформації про виявлення підозрілих предметів або загрози здійснення вибухів;

11. Підтримання публічного порядку на повітряному судні;

12. Контроль за станом і використанням об'єктів торгівлі.

За даними 2018 року на території аеропортів України найчастіше вчинялися такі види правопорушень [10, с. 94]:

- незаконні виробництво, придбання, зберігання, перевезення, пересилання наркотичних засобів або психотропних речовин без мети збуту в невеликих розмірах (ст. 44 Кодексу України про адміністративні правопорушення - КУпАП);

- дрібне викрадення чужого майна (ст. 51 КУПАП); порушення правил безпеки польотів (ст. 111 КУпАП);

- порушення правил перевезення небезпечних речовин і предметів на транспорті (ст. 133 КУпАП);

- порушення правил, спрямованих на забезпечення схоронності вантажів на повітряному транспорті (ст. 137 КУпАП);

- $\quad$ порушення правил торгівлі пивом, алкогольними, слабоалкогольними напоями і тютюновими виробами (ст. 156 КУПАП);

- порушення правил про валютні операції (ст. 162 КУпАП);

- порушення порядку провадження господарської діяльності (ст. 164 КУПАП);

КУПАП);

- дрібне хуліганство (ст. 173

- розпивання пива, алкогольних, слабоалкогольних напоїв $\mathrm{y}$ заборонених законом місцях або поява у громадських місцях у п'яному вигляді (ст. 178 КУпАП);

- азартні ігри, ворожіння в громадських місцях (ст. 181 КУпАП);

- заняття проституцією (ст. 181 КУПАП);

- завідомо неправдивий виклик спеціальних служб (ст. 183 КУПАП);

- порушення громадянами правил зберігання, носіння або перевезення нагородної вогнепальної, холодної чи пневматичної зброї i бойових припасів (ст.191 КУПАП);

- проживання без паспорта громадянина України або без реєстрації місця проживання (ст. 197 КУПАП);

- порушення прикордонного режиму, режиму в пунктах пропуску через державний кордон України або режимних правил у контрольних пунктах в'їзду-виїзду (ст. 202 КУпАП); 
- порушення іноземцями та особами без громадянства правил перебування в Україні і транзитного проїзду через територію України (ст. 203 КУпАП) та ін.

Необхідно зазначити, що хоча Національна поліція України і відіграє провідну роль у забезпеченні публічного порядку і безпеки на авіаційному транспорті, але вона не $\epsilon$ єдиним органом, який забезпечує публічну безпеку в цивільній авіації. Взагалі усіх учасників відносин, що виникають під час забезпечення публічної безпеки на авіаційному транспорті можна поділити за чотирма ознаками: пріоритетом правоохоронної функції (здійснення, нагляд, контроль); за зв'язком із Україною (вітчизняний, іноземний); за часом перебування на території аеропортів (тимчасовий, постійний); за критерієм соціально-правової позиції стосовно правил поведінки (зобов'язаний дотримуватись, контролює дотримання).

Згідно Постанови Кабінету Мiністрів України, головним органом у системі центральних органів виконавчої влади, щодо формування та реалізації державної політики у сфері авіаційного транспорту та використання повітряного простору України $€$ Міністерство інфраструктури України (Мінінфраструктури) [14]. А центральним органом виконавчої влади уповноваженим 3 питань цивільної авіації (та авіаційної безпеки цивільної авіації) $є$ Державна авіаційна служба (Державіаслужба). Діяльність останньої регламентується Постановою Кабінету Міністрів України від 8 жовтня 2014 року № 520 [15] та спрямовується і координується Міністром Мінінфраструктури за допомогою Директорату авіаційного транспорту Мінінфраструктури.

Разом з Державіаслужбою Державну програму авіаційної безпеки цивільної авіації забезпечує ряд Центральних органів виконавчої влади. Серед них органи, що забезпечують або реалізують: формування державної політики у сфері транспорту; формування державної політики у сфері охорони здоров'я; державну політику у сфері цивільного захисту, державну політику у сфері охорони державного кордону; державну митну політику; а також Служба безпеки України; Міністерство оборони України та Національна поліція України (поліція) тощо.

Окрім того, авіаційну безпеку в суб'єктах авіаційної діяльності забезпечують служби авіаційної безпеки. Які діють відповідно до «Положень про службу авіаційної безпеки суб'єкта авіаційної діяльності»[16] та «Правил сертифікації служб авіаційної безпеки»[17].

Виконання Державної програми авіаційної безпеки цивільної авіації також покладається на окремих посадових осіб з числа працівників аеропортів, аеродромів, експлуатантів.

Особливої уваги заслуговує діяльність державних інспекторів 3 авіаційного нагляду Державіаслужби, яких доречи розрізняють за такими напрямками діяльності: державний інспектор з безпеки авіації; державний інспектор з льотної придатності; державний інспектор 3 льотної експлуатації[18].

Також необхідно відмітити наявність таких спеціальних підрозділів служби авіаційної безпеки аеропортів, як воєнізована охорона. На них покладаються обов'язки 3 охорони повітряних суден, об'єктів 
та майна суб'єктів авіаційної діяльності, підтримання внутрішнього об'єктового режиму в контрольованих зонах аеропортів, виконання інших завдань.

Окрім того у організації і забезпеченні внутрішнього об'єктового та пропускного режимів задіяні й інші служби та посадові особи 3 числа суб'єктів авіаційної діяльності (незалежно від форми власності та підпорядкування).Таким чином безпека в авіації має багато напрямків та складових, які передбачають злагоджену роботу низки органів та служб. Взаємодія Державної авіаційної служби з правоохоронними органами з питань забезпечення безпеки цивільної авіації та окремих питань публічної безпеки регламентується Постановою Кабінету Міністрів від 26 червня 2019 р. № 550 [19]. Основними формами такої взаємодії $€$ організація взаємного інформування, планування i проведення спільних заходів щодо виявлення, припинення і попередження правопорушень ... , надання допомоги правоохоронними органами державним інспекторам та особам, уповноваженим на проведення перевірок, у виконанні ними службових обов'язків щодо інспектування i перевірок та припинення незаконних дій осіб, які перешкоджають виконанню зазначених обов'язків [19, п. 2 Порядку] тощо.

Висновки. Спираючись на проведений аналіз структури безпеки авіації та чинної нормативноправової бази можна стверджувати наступне.

1. Авіацію слід розглядати як велику самостійну галузь економіки, яка активно розвивається державою. Інфраструктуру авіації, їі функціонування та здійснення польотної дія- льності можна вважати сферою 3 підвищеним рівнем небезпеки.

2. Поняття безпеки в галузі авіації $\epsilon$ багатоаспектним та комплексним. Воно охоплює організаційні й технічні питання, напрямки запобігання та протидії злочинам і порушенням, проблеми додержання вітчизняних та міжнародних стандартів.

3. Організація безпеки в авіації включає в себе діяльність із забезпечення: національної безпеки, воєнної безпеки та оборони держави, авіаційної безпеки (яка має специфічну складну структуру), публічного порядку і громадської безпеки тощо.

4. Забезпечення публічного порядку пов'язане з питаннями громадської безпеки і відтак не стосується державної авіації, в галузі якої уповноваженим органом виконавчої влади є Міністерство оборони України. Говорячи про публічний порядок i безпеку на авіаційному транспорті слід розуміти виключно цивільну авіацію.

5. Публічний порядок та безпека на авіаційному транспорті забезпечуються в першу чергу Національною поліцією України. Проте поліція не є єдиним суб'єктом забезпечення публічної безпеки. У виконання завдань $з$ публічної безпеки бере участь сукупність окремих органів. Необхідно відмітити, що одні й ті самі державні органи одночасно беруть участь у забезпеченні різних видів безпеки виконуючи при цьому різні завдання.

6. Нормативно-правова база, якою регулюється сфера цивільної авіації України, знаходиться в стані активного реформування. Особливістю такого реформування $\epsilon$ наявність великої кількості міжнародних 
правових конвенцій та документів (переважно $з$ питань безпеки), на забезпечення відповідності яким i спрямовані зміни у національному законодавстві.

7. Уповноваженим центральним органом виконавчої влади 3 питань авіаційної безпеки цивільної авіації $є$ Державна авіаційна служба України. У забезпеченні програм авіаційної безпеки окрім Державіаслужби бере участь велика кількість органів, організацій, посадових осіб різної форми власності. Авіаційна безпека $\epsilon$ складовою безпеки авіації, яка в свою чергу перетинається із забезпеченням публічного порядку та безпеки на авіаційному транспорті.

8. У якості специфічної форми взаємодії суб'єктів забезпечення безпеки в цивільній авіації можна розглядати різні види правових режимів, наприклад, внутрішньооб'єктовий та пропускний.

9. Складна структура спільних дій суб'єктів забезпечення без- пеки цивільної авіації у середині 2019 року набула позитивних змін пов'язаних із затвердженням Кабінетом Міністрів України «Порядку взаємодії Державної авіаційної служби 3 правоохоронними органами з питань забезпечення безпеки цивільної авіації».

10. Національна поліція України реалізує виконання завдань з забезпечення публічного порядку та безпеки на авіаційному транспорті через Департамент превентивної діяльності Національної поліції України та його підрозділи превентивної діяльності в аеропортах. Аналіз особливостей діяльності цих підрозділів свідчить про те, що їх діяльність переважно містить превентивні, профілактичні, попереджувальні заходи, які у своїй більшості спрямовані на запобігання та припинення адміністративних порушень, що не мають значних наслідків.

\section{Список використаних джерел}

1. Законодавство України, Термін: «Авіація, як галузь». URL: https:// zakon.rada.gov.ua/laws/term/ru/259?lang=uk (дата звернення: 20.12.2019).

2. Про схвалення Національної транспортної стратегії України на період до 2030 року : Розпорядження Кабінету Міністрів України від 30.05.2018 р. № 430-р.

3. «Діяльність Державіаслужби - 2019. Щорічний звіт керівника» URL: https://avia.gov.ua/oleksandr-bilchuk-vistupiv-z-publichnim-zvitom-pro-pidsumkidiyalnosti-derzhavnoyi-aviatsijnoyi-sluzhbi-ukrayini-za-2019-rik/ (дата звернення: 25.12.2019).

4. Повітряний кодекс України від 19.05.2011 р. № 3393-VI / Відомості Верховної Ради України (ВВР), 2011, № 48-49, ст. 536.

5. Про Національну безпеку України : Закон України від 21.06.2018 р. № 2469VIII / Відомості Верховної Ради (ВВР), 2018, № 31, ст. 241.

6. Пономарьов С.П. Адміністративно-правове забезпечення діяльності сектору безпеки і оборони України : дис. ... доктор юрид. наук : 12.00.07. Харків, 2018. 483 с.

7. Законодавство України, Термін: «Громадський порядок». URL: https:// zakon.rada.gov.ua/laws/term/5670 (дата звернення: 11.11.2019).

8. Юридична енциклопедія [під ред. Ю.С. Шемшученко]. Київ : Вид-во «Українська енциклопедія» ім. М.П. Бажана, 1998. Т. 1. 672 с. 
9. Подоляка А. М. Адміністративно-правове регулювання охорони громадського порядку в Україні : автореф. дис. на здобуття наук. ступеня д-ра юрид. наук : спец. 12.00.07 «Адміністративне право і процес ; фінансове право; інформаційне право». Київ : Ін-т законодавства ВР України, 2009. 40 с.

10. Кононець В. П. Адміністративно-юрисдикційна діяльність поліції щодо забезпечення публічного порядку та безпеки в аеропортах: монографія. Дніпро: ДДУВС, 2018. 156 с.

11. Веремеенко И. И. Механизм административно-правового регулирования в сфере охраны общественного порядка. Москва, 1982. Ч. 1. 96 с.

12. Мінка Т. П. Адміністративно-правові режими та їх забезпечення органами внутрішніх справ : дис. ... д-ра юрид. наук : 12.00.07. Дніпропетровськ, 2011. 614 с.

13. Про затвердження Положення про Департамент превентивної діяльності Національної поліції України : Наказ Національної поліції України від 27.11.2015 р. № 123.

14. Про затвердження Положення про Міністерство інфраструктури України : Постанова Кабінету Міністрів України від 30 червня 2015 р. № 460.

15. Про затвердження Положення про Державну авіаційну службу України : Постанова Кабінету Міністрів України від 8 жовтня 2014 р. № 520.

16. Про затвердження Положення про службу авіаційної безпеки авіаційного суб'єкта : Наказ Державної служби України з нагляду за забезпеченням безпеки авіації від 15.03.2005 р. № 188.

17. Про затвердження Правил сертифікації служб авіаційної безпеки в Україні : Наказ Державної служби України з нагляду за забезпеченням безпеки авіації від 02.06.2006 p. № 397.

18. Положення про державного інспектора з авіаційного нагляду у Державній авіаційній службі України: Наказ Міністерства транспорту та зв'язку України від 09.02.2010 р. № 68.

19. Про затвердження Порядку взаємодії Державної авіаційної служби з правоохоронними органами з питань забезпечення безпеки цивільної авіації : Постанова Кабінету Міністрів України від 26 червня 2019 р. № 550.

\section{References}

1. Yuridichna enciklopediya [pid red. Yu.S. Shemshuchenko]. (1998). Kiyiv: Vid-vo «Ukrayinska enciklopediya» im. M.P. Bazhana, T. 1 [in Ukrainian].

2. Podolyaka, A. M. (2009). Administrativno-pravove regulyuvannya ohoroni gromadskogo poryadku $v$ Ukrayini (Avtoref. dis). Kiyiv: In-t zakonodavstva VR Ukrayini [in Ukrainian].

3. Kononec, V. P. (2018). Administrativno-yurisdikcijna diyalnist policiyi shodo zabezpechennya publichnogo poryadku ta bezpeki v aeroportah. Dnipro : DDUVS [in Ukrainian].

4. Veremeenko, I. I. (1982). Mehanizm administrativno-pravovogo regulirovaniya $v$ sfere ohrany obshestvennogo poryadka. Moskva [in Russian].

5. Minka, T. P. (2011). Administrativno-pravovi rezhimi ta yih zabezpechennya organami vnutrishnih sprav (Dis. d-ra yurid. nauk). Dnipropetrovsk [in Ukrainian]. 
O. Brusakova, Candidate of Philosophy, Dean of faculty № 6 of Kharkiv National University of Internal Affairs

ORCID: 0000-0001-8616-042

\section{Administrative legal provision of public order and safety in aviation transport}

The article is aimed at revealing the peculiarities of administrative and legal support of public order and safety in aviation transport. It is justified that aviation should be considered as a large independent branch of economy, which is actively developing by the state. Aviation infrastructure, its operation and operations can be considered as a high risk area. Aviation security is an integral part of aviation security, which in turn intersects with public order and aviation security.

The paper describes the characteristics of aviation transport, its current state and vector of development. The structure and structure of the legal framework governing the specified sphere of activity are investigated.

The complex of issues related to aviation safety is considered, attention is paid to the system of subjects, whose activity is aimed at providing it. It is noted that, although the National Police of Ukraine plays a leading role in ensuring public order and safety in aviation transport, it is not the only body providing public safety in civil aviation. In general, all participants in the relations that arise in the course of ensuring public safety in aviation can be divided into four characteristics: the priority of the law enforcement function (implementation, supervision, control); in connection with Ukraine (domestic, foreign); on time at the airport (temporary, permanent); according to the criterion of social and legal position regarding the rules of conduct (obliged to observe, controls compliance). The National Police of Ukraine implements the tasks of ensuring public order and safety in aviation through the Department of Preventive Activity of the National Police of Ukraine and its preventive activities units at airports. The analysis of the peculiarities of the activities of these units shows that their activities mainly contain preventive, preventive, preventive measures, which in the majority are aimed at preventing and ending administrative violations, which do not have significant consequences.

As a result of the analysis of the norms of legislation and the achievements of scientists, the relation between the concepts of "public order in aviation transport" and "aviation security" was clarified, conclusions were drawn about the application of different types of legal regimes that take place in aviation, as well as about the complex system of communications between sub acts that ensure adherence to these regimes. Prospective directions of further scientific researches in the direction of providing and increasing the level of public order and safety in aviation are highlighted.

Keywords: aviation security; public order; public security; national security. 